\title{
Influence of Pre-sowing Treatments, Sowing Positions and Age of Stones after Extraction from Fruit on Germination and Vigour of Mango
}

\author{
U.R. Reshma, S. Simi ${ }^{1}$
}

10.18805/IJARe.A-5792

\begin{abstract}
Background: Mango stones are in general recalcitrant. Moreover, they are available only during April- May months which are the drier parts of the year. So stone germination and plant vigour are very low. Proper seed orientation, age of stones after extraction from fruit and pre-sowing treatments need to be taken into consideration for inducing early germination, boosting growth, enhancing the seedling vigour and reducing the mortality.

Methods: The experiment was laid out in factorial completely randomized design with forty two treatment combinations replicated thrice. The treatments were comprised of two sowing positions viz., flat and stalk end up, three age of stones after extraction from fruit, viz., fresh extracted, 10 days and 20 days after extraction and seven pre-sowing treatments viz., 100 ppm GA $\mathrm{G}_{3}, 200 \mathrm{ppm} \mathrm{GA}, 1$ ppm $\mathrm{KNO}_{3}, 2$ ppm $\mathrm{KNO}_{3}$, cow dung slurry, water, control and their combinations.

Result: Stalk end up sowing of freshly extracted stones pre-treated with 200 ppm $\mathrm{GA}_{3}$ for 24 hours recorded better germination and vigour of mango seedlings.
\end{abstract}

Key words: Age, Germination, Pre-sowing treatments, Sowing positions, Vigour.

\section{INTRODUCTION}

Being a recalcitrant seed, the viability of mango stone is comparatively low. There is only about $12-50$ per cent germination when sown within a month after extraction (Gill et al., 1985). The availability of fruits are confined to mainly one season. So the stones which are available during a particular season need to be properly utilized and exploited in an effective way for raising strong, healthy and actively growing rootstocks.

Usually the mango stones are available during AprilMay months i.e. drier part of the year. Therefore the stone germination and plant vigour are critically very low. In our country, mainly non-descriptive monoembryonic seedlings are utilized for rootstock purpose (Patel et al., 2016). Hence there is a great variation in stone germination, vigour and further seedling development depending on the location and region, where the rootstocks are raised.

Generally the stones begin to germinate 12 to 15 days after sowing, but may take about a month or even more to complete the germination. The sporadic and slow germination in mango is due to the stony endocarp and consequently seedlings take more time to attain graftable size. It is necessary to improve stone germination and enhance seedling growth for synchronization, rapid seedling emergence and healthy rootstocks within a short period of time (Patel et al., 2017). To achieve a perceptible difference in enhancing germination, rapid emergence, boosting up of growth and reducing mortality, sowing positions (seed orientation), age of stone after extraction from fruit and various pre-sowing treatments need to be taken into consideration.
Department of Fruit Science, College of Agriculture, Vellayani, Thiruvananthapuram-695 522, Kerala, India.

'Department of Horticulture, College of Agriculture, Vellayani, Thiruvananthapuram-695 522, Kerala, India.

Corresponding Author: U.R. Reshma, Department of Fruit Science, College of Agriculture, Vellayani, Thiruvananthapuram-695 522, Kerala, India. Email: reshmaraveendran566@gmail.com

How to cite this article: Reshma, U.R. and Simi, S. (2021). Influence of Pre-sowing Treatments, Sowing Positions and Age of Stones after Extraction from Fruit on Germination and Vigour of Mango. Indian Journal of Agricultural Research. 55(5): 527-534. DOI: 10.18805/IJARe.A-5792.

Submitted: 15-04-2021 Accepted: 24-06-2021 Online: 03-08-2021

An experiment was therefore undertaken to assess the effect of pre-sowing treatments, sowing positions and age of stones after extraction from the fruit with the main objectives of increasing germination percentage and producing vigorous rootstocks in order to meet the ever rising market demand and to evolve the best technology for producing high quality mango planting material in a short period of time.

\section{MATERIALS AND METHODS}

The present study was carried out during 2018 - 2019 at the College of Agriculture, Vellayani, Thiruvananthapuram, Kerala. The experiment was laid out in factorial completely randomized block design with 42 treatments. The treatments comprise of different combinations of 2 sowing positions (flat and stalk end up), 3 different age group of stones after extraction from fruit (freshly extracted stone, 10 days after 
extraction and 20 days after extraction) and 7 pre-sowing treatments $\left(\mathrm{GA}_{3}-100, \mathrm{GA}_{3} 200 \mathrm{ppm}, \mathrm{KNO}_{3}-1 \mathrm{ppm}, \mathrm{KNO}_{3}\right.$ $2 \mathrm{ppm}$, cow dung slurry, water and control). Fruits of 'Kotookonam Varikka' variety of mango were selected for the study. The average stone weight of each age groups were recorded accordingly. The average stone weight was $29.85 \mathrm{~g}$ for freshly harvested, $28.02 \mathrm{~g}$ for stones which were sown 10 days after extraction and $24.63 \mathrm{~g}$ for the stones which were sown 20 days after extraction respectively. After extraction, the stones were washed thoroughly and were soaked in various pre-soaking solutions for 24 hours prior to sowing. The pre-treated mango stones of different age groups were sown at proper spacing in stalk end up and flat positions in the seed bed. The germination of stones started 15 days after sowing and continued upto 55 days. Observations were recorded daily for germination parameters and vegetative parameters like seedling length, dry weight and seedling vigour index I and II were recorded 4 months after sowing.

The germination percentage was calculated as follows; Germination percentage $=$

$$
\frac{\text { Number of stones germinated }}{\text { Total number of stones sown }} \times 100
$$

The rate of germination was calculated as;

Rate of germination =

Germination percentage

Number of days taken for germination

(Bewley and Black, 1982)

Vigour index - I (growth basis) and Vigour index - II (weight basis) were calculated using the formula given by Kumar et al. (2007) as follows;

Vigour Index $-\mathrm{I}=$ Germination percentage $(\%) \times[$ Shoot length $(\mathrm{cm})+$ Root length $(\mathrm{cm})]$

Vigour Index - II = Germination percentage $(\%) \times$ Dry weight of seedling $(\mathrm{g})$

The experimental data recorded was subjected to statistical analysis as per the method suggested by Panse and Sukhatme (1967). Treatment means were separated using $\mathrm{F}$ test values at $5 \%$ level of significance.

\section{RESULTS AND DISCUSSION}

Significant differences were observed among the pre-sowing treatments, sowing position and age of stone after extraction from the fruit for germination characters. Statistically analysed results are given in Table 1 and 2 and are explained under following subheadings.

\section{Effect of sowing positions}

The perusal of data presented in Table 1 clearly indicated that the earliness in germination (22.95 days), the least number of days taken for 50 per cent germination (31.75 days), higher germination percentage (60.85\%) and germination rate $(0.47)$ were in stalk end up position as compared to flat method of sowing.

The stones sown in stalk end up position produced significantly higher seedling length $(34.63 \mathrm{~cm})$, the highest seedling dry weight $(9.77 \mathrm{~g})$ and produced the seedlings with higher vigour index-I (2176.50) and vigour index- II (603.27) on growth and weight basis (Fig 1 and Fig 2) accordingly than flat position.

The amount of energy required to accomplish germination varies according to genotype and seed orientation on seed bed because of the quantity of stored nutrients, especially endosperm and positioning of micropyle, respectively in cashew (Hammed et al., 2014). Naturally, the radicle has a positive geotropism whereas the shoot of the germinating seed has a negative geotropism. Supporting the upcoming response of the seedling to the stimulus (gravity) is highly correlated with the orientation of micropyle. The tip of the root bends downward if the seeds oriented vertically upward with respect to micropyle. The roots of seed sown by mycropyle in vertically upright position need to curve over the seed itself in order to grow in downward (normal) direction in tree species (Coutts, 1989).

Mango stones with stalk-end up position of sowing places the micropyle in the most suitable position, i.e., pointing downward, the roots of the seed grew easily and directly downward (does not require bending), which requires less energy for germination and radicle emerge from the embryo (Vijaya and Satyanarayana, 2004). Hence it resulted with highest germination percentage and earliness in germination in Stalk end up method.

The seedlings whose roots grow properly without any curvature will establish well for its function and growth, which can ultimately improve the performance. Hence, stalk end up method resulted in the highest seedling length and dry weight which ultimately resulted in better seedling vigour indices, both on growth and weight basis over the flat method of sowing.

The improper orientation of seeds could impoverish the emerging embryo for needed quantum of oxygen which could lead to the synthesis of higher amount of ethanol and pyruvate in the plant system and finally leads to the death of the emerging embryo (Bewley, 1997). This might be the probable reason for reduced germination and poor quantitative plant vigour in seeds sown in flat method.

\section{Effect of age of stones after extraction from the fruit}

The highest germination percentage, earliness in germination, rate of germination, higher seedling length, seedling dry weight, seedling vigour indices on growth basis and weight basis were the best for freshly harvested stones (Table 1).

The germination ability of a seed was directly related to its moisture content as well as the rate at which seeds lose its moisture thereby affecting the viability in Calamus species (Patil and Krishna, 2016). The reduction in viability 


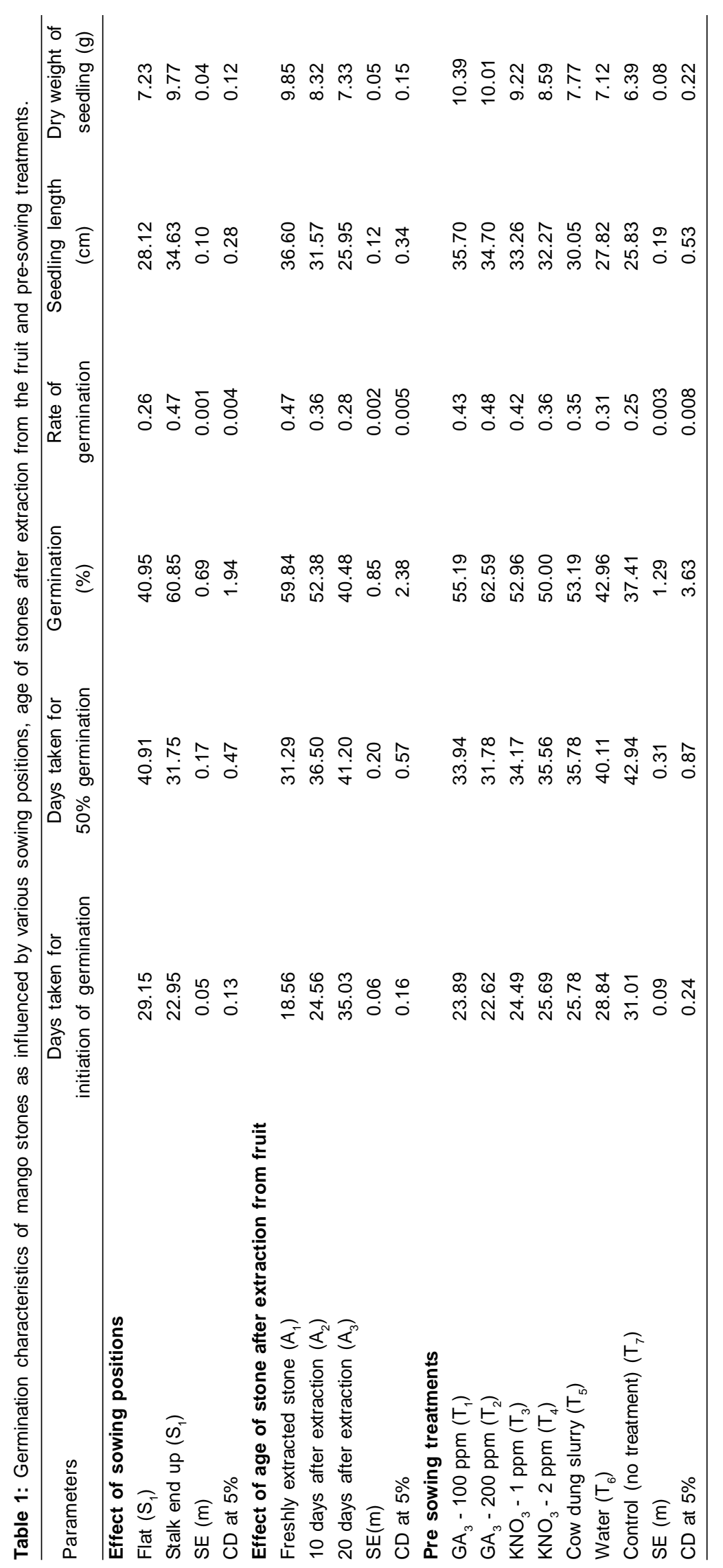


and vigour were proportional to increased leaching of metabolites from seeds and decreased dehydrogenated activity of seeds. The leaching of metabolites increases with decreased seed moisture content during storage.

The freshly extracted seeds had considerable amount of post imbibition hydrolysis of non-reducing sugars and DNA-P (DNA polymerase) which resulting in initiation of protein synthesis, little or none could be observed as age advances in mango (Chandra, 1980). The higher expression of DNA-P in imbibed seeds enhancing the protection against DNA damage and allows successful germination of rice seeds (Sihi et al., 2015). Germination became progressively slower as the age advanced.

\section{Effect of pre-sowing treatments}

It is evident from Table 1 that the pre-sowing treatments had a significant effect on growth and vigour of mango seedlings. The stones treated with 200 ppm GA $\mathrm{F}_{3}$ recorded the least number of days for initiation of germination (22.62 days), for 50 per cent germination (31.78 days), the highest germination percentage $(62.59 \%)$ and rate of germination (0.48), significantly higher vigour index-I (2310.02) and vigour index-II (657.09) on growth and weight basis (Fig 1 and Fig 2). The highest seedling length $(35.70 \mathrm{~cm})$ and dry weight $(10.39 \mathrm{~g})$ of the mango seedlings were observed in $100 \mathrm{ppm} \mathrm{GA}_{3}$. The poorest germination, vigour and growth characteristics of mango seedlings were observed in control (without any treatment).

The earliest stone germination in $\mathrm{GA}_{3}$ might be due to the increased concentration of endogenous auxin content due to the $\mathrm{GA}_{3}$ application as the $\mathrm{GA}_{3}$ is the vital component of auxin signalling pathway (Ross et al., 2002). In aonla, the increased level of auxin and enhanced enzymatic activities along with the repression of inhibitors might be the probable reasons for faster germination. $\mathrm{GA}_{3}$ might have also triggered the starch hydrolysis and their translocation to the growing seedlings thereby inducing early germination (Rajmanickam et al., 2004).

The presence of $\mathrm{GA}_{3}$ inside the seed which stimulates the imbibition process on subsequent seed germination. Presoaking treatment of $\mathrm{GA}_{3}$ might have affected directly and altered various enzymatic reactions, synthesis of proteins and conversion of starch into sugars involved in the process of germination (Paleg, 1960). On the other hand, $\mathrm{GA}_{3}$ also

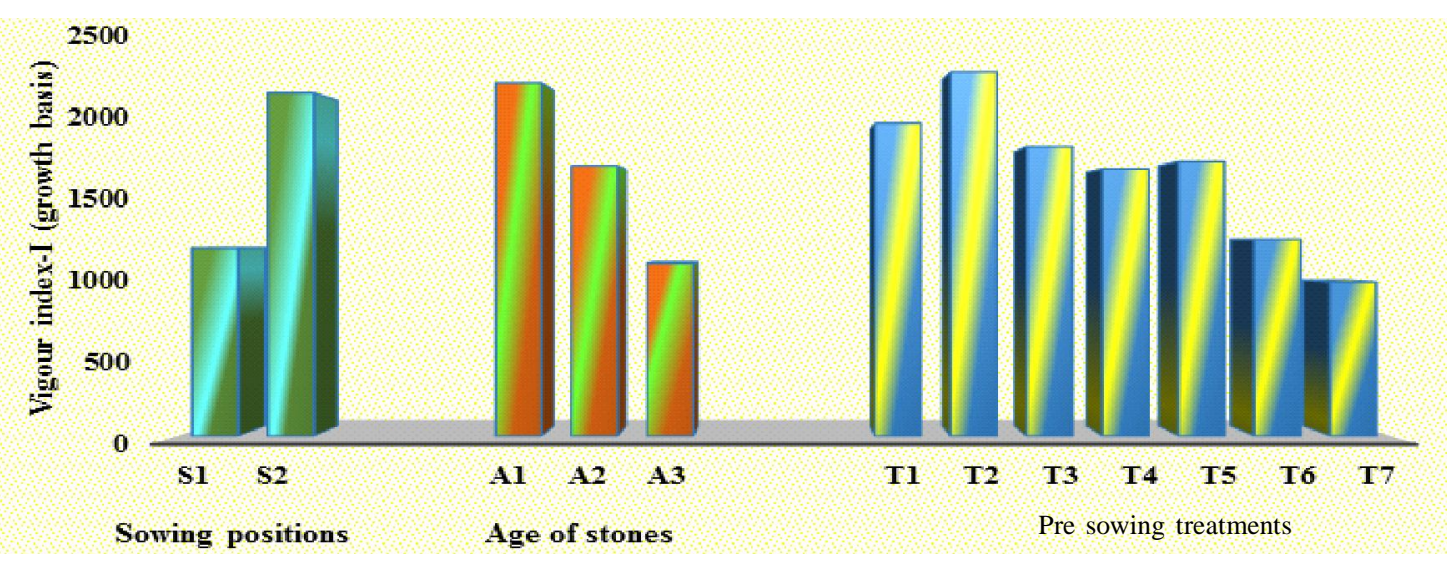

Fig 1: Effect of sowing positions, age of stones after extraction from the fruit and pre sowing treatments on vigour index -I (growth basis) of mango seedlings.

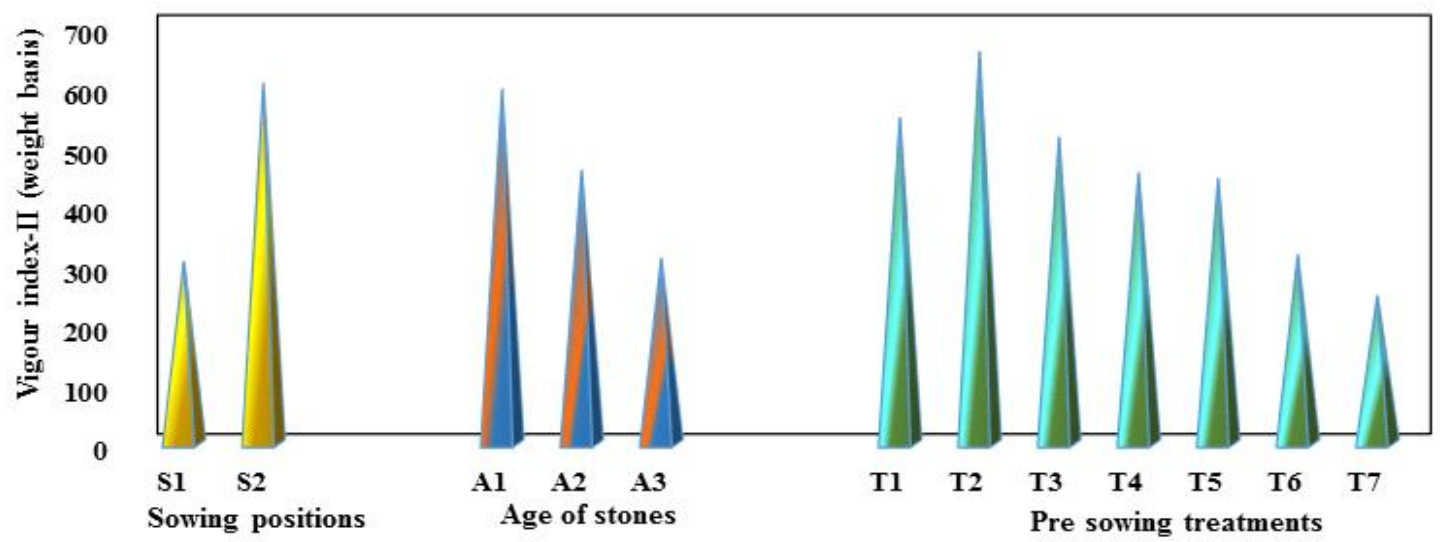

Fig 2: Effect of sowing positions, age of stones after extraction from the fruit and pre sowing treatments on vigour index -II (weight basis) of mango seedlings. 


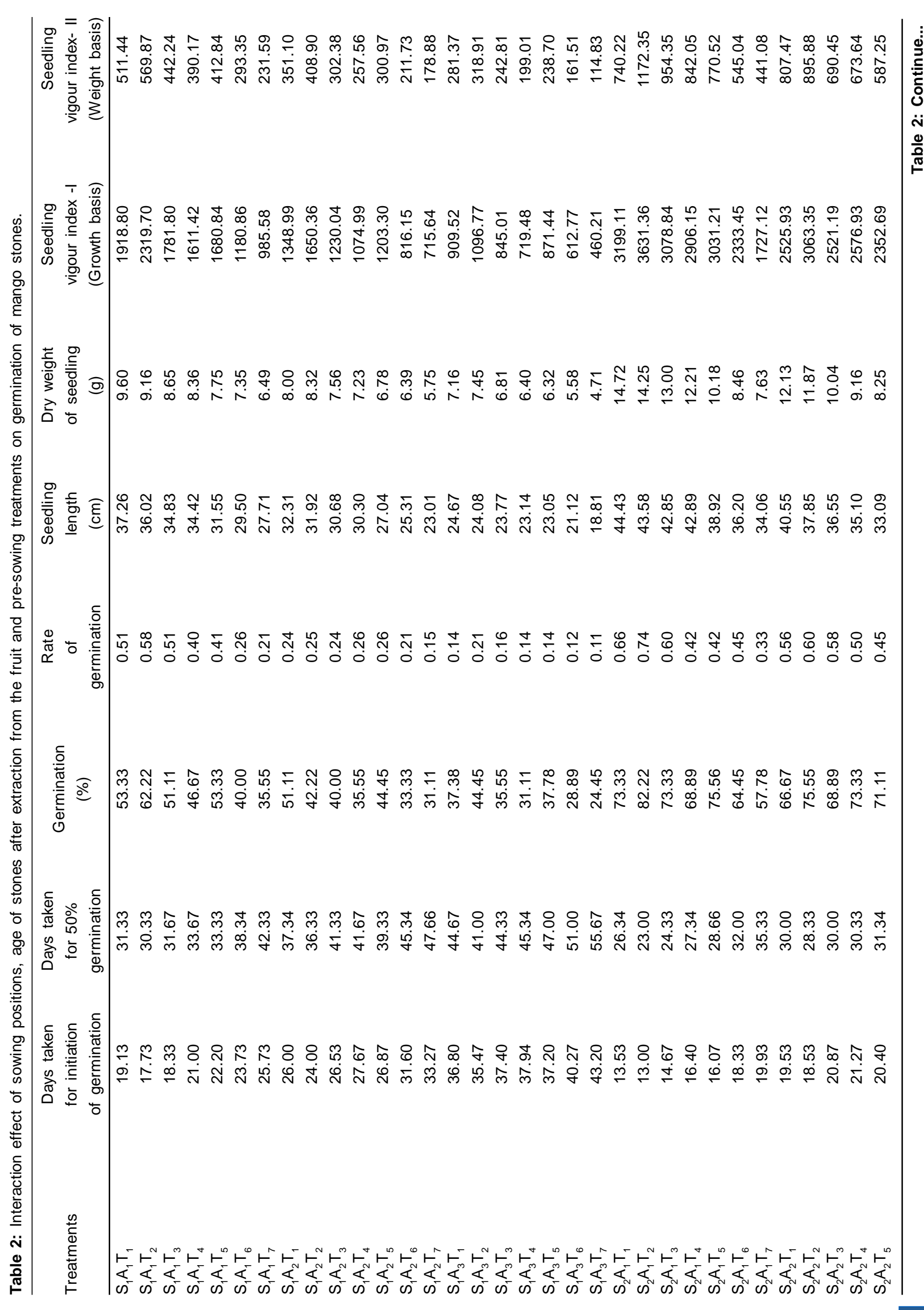




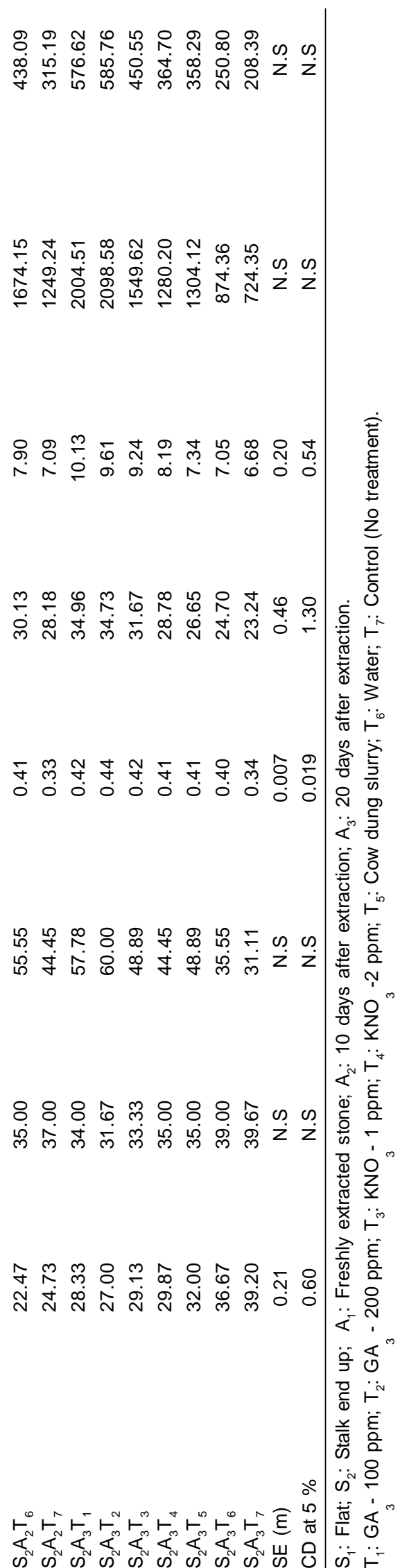

induces the denovo synthesis of proteolytic enzymes like ribonuclease and $\alpha$-Amylase. The enzyme $\alpha$-amylase and accompanying hydrolytic enzyme(s) successively hydrolyse the starch in endosperm thereby providing essential sugars for growth initiation processes and also liberate chemical energy which is utilized for RNA synthesis, activation of embryo as well as the suppression of inhibition which in turn resulted in higher germination (Copeland and Mcdonald, 1995). $\mathrm{GA}_{3}$ treatment also have an ability to overrule the thermodormancy, photo dormancy, dormancy imposed by incomplete development of embryo, presence of various germination inhibitors as well as mechanical barriers in peach (Diaz and Martin, 1971).

In general, the regulation of growth by gibberellins and potassium nitrate relates virtually to its stem elongation properties, especially due to the enhancement of metabolites responsible for cell division and enlargement of cell. These chemicals act exclusively on stem elongation by loosening the cell wall, increasing the concentration of solutes by increasing the extensibility of cell wall, stimulating cell wall synthesis, reducing the cell wall rigidity and by increasing cell division leading to more efficient growth. The indirect effect caused by these chemicals on stem elongation is by increasing the IAA synthesis that leads to more vegetative growth (Leopold and Krieddemann, 1983).

Increase in dry weight of seedlings by $\mathrm{GA}_{3}$ application might be due to the improved mobilization of the nutrients, which promotes the plant growth and development in better way. In khirnee the $\mathrm{GA}_{3}$ treatment might have resulted into higher production of photosynthates and their translocation through phloem tissue to the root zone might have led to increase in the production of lateral roots thereby increasing the root length (Vachhani et al., 2014). The exogenous application of $\mathrm{GA}_{3}$ also triggered the activity of gluconeogenic enzyme during the early stages of seed germination and this could be a probable reason for improved vigour characteristics which directly reflected on more production of lateral roots as well as increased root length, thereby improved the shoot growth in tamarind (Vasantha et al. 2014). This might have resulted in increased total dry weight of the seedling. In pea seedlings the cumulative effect of better root and shoot growth as well as more production of lateral roots have led to overall assimilation and redistribution of photosynthates within the plant system, thereby promoting the better growth and development (Brian and Hemming, 1955).

The better results with respect to vigour indices might be due to the cumulative effect of higher germination percentage, shoot length, root length and seedling dry weight under $\mathrm{GA}_{3}$ treatment.

\section{Interaction effect}

Interaction effects (Table 2) also indicated that the sowing of freshly extracted stones by stalk end up method after treatment with $200 \mathrm{ppm} \mathrm{GA}$ for 24 hours resulted in significantly higher germination rate $(0.74)$ and minimum 


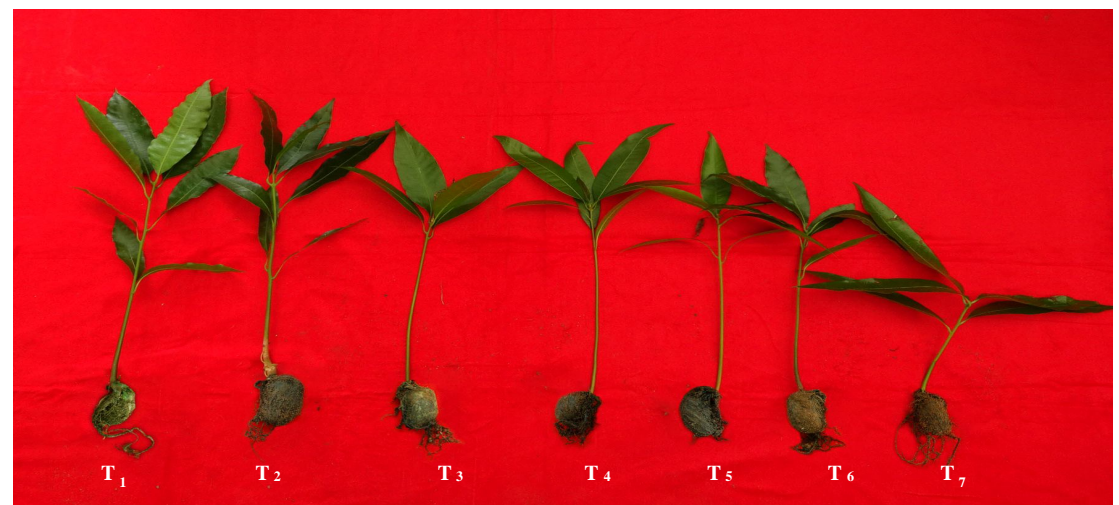

Fig 3: Effect of pre sowing treatments on seedling length of freshly harvested mango stones sown in stalk end up method.

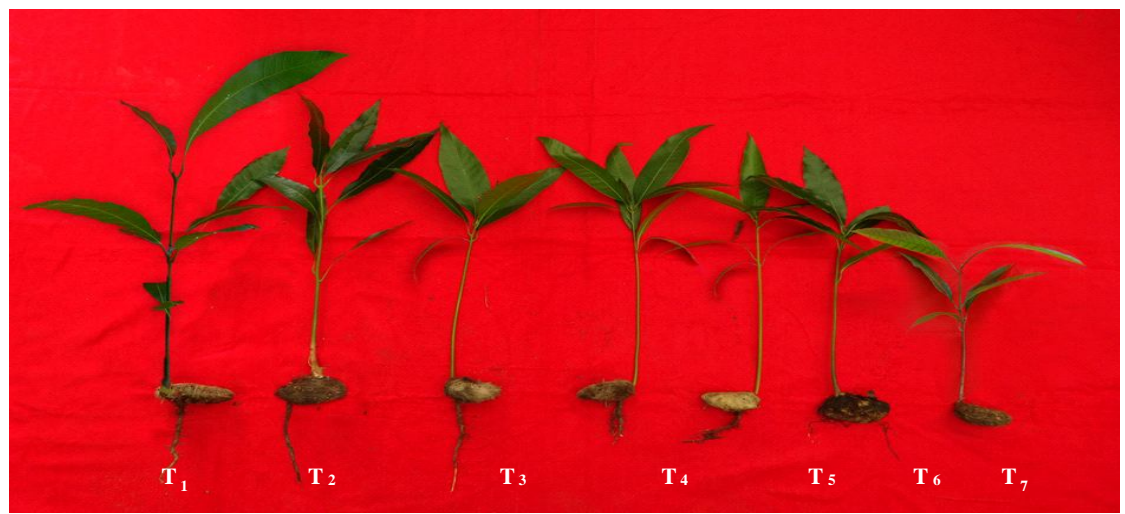

Fig 4: Effect of pre sowing treatments on seedling length of freshly harvested mango stones sown in flat method.

days for initiation of germination (13.00 days). Whereas the highest seedling length $(44.43 \mathrm{~cm})$ and dry weight $(14.72 \mathrm{~g})$ was recorded in stalk end up method after treatment with 100 ppm GA for 24 hours (Fig 3). Sowing of stones 20 days after extraction from the fruit by flat method without any pre-sowing treatments resulted in poor germination and vigour of mango seedlings (Fig 4).

\section{CONCLUSION}

Germination became progressively slower as the age advanced. The micropyle positioning while sowing has direct implications on seedling quality as it determines the uniformity, speed as well as rate of germination. The $\mathrm{GA}_{3}$ treatment resulted in earliest germination, boosting the growth, enhancing the seedling vigour and reducing the mortality. Hence the cumulative effect of viable and physiologically more active freshly harvested stones which were pre-treated with $\mathrm{GA}_{3}$ and sown in micropyle pointing downward (stalk end up) position resulted in better germination and vigour of mango seedlings.

\section{REFERENCES}

Bewley, J.D. (1997). Seed germination and dormancy. Plant Cell. 9: 1055-1066.

Bewley, J.D. and Black, B.M. (1982). Physiology and Development and Germination. Part II. Springer verlag, New Delhi. pp. 58.
Brian, P.W. and Hemming, H.G. (1955). The effect of GA on shoot growth of pea seedlings. Physiologia Plantarum. 8: 669681.

Chandra, N. (1980). Some physiological changes accompanying loss of viability of the seeds of Mangifera indica L. Plant Biochemistry Journal. 7(2): 105-109.

Coutts, M.P. (1989). Factors affecting the direction of growth of tree roots: Forest tree physiology. Annals for Science. 46: 277-287.

Copeland, L.O. and Mcdonald, M.B. (1995). Principles of Seed Science and Technology, $4^{\text {th }}$ edn. Norwell, Massachusetts. Kluwer Academic Publishers. Annals of Botany. 89: 488.

Diaz, D.H. and Martin, G.C. (1971). Peach seed dormancy in relation to inhibitors and applied growth substance. Journal of American Society of Horticulture Science. 97: 651-654.

Gill, S., Bal, J. and Sandhu, A. (1985). Raising fruit nursery. Kalini Publishers, Ludhiana. pp.11.

Hammed, A.L., Aliyu, O.M., Dada, E.K. and Egbewale, S.O. (2014). Cultivar type and nut-sowing orientation influence germination and plant vigour in Cashew (Anacardium occidentale L.). International Journal of Fruit Science. 14: 69-80.

Kumar, Y.H.S., Swamy, G.S.K., Patil, C.P., Kanamadi, V.C. and Kumar, P. (2007). Effect of pre-soaking treatments on germination, growth, vigour index and vigour of rootstocks in mango. Journal of Asian Horticulture. 3 (3): 157-161.

Leopold, A.C. and Krieddemann, E.T (1983). Plant Growth and Development. Tata Mac Graw Hill Pub. Co. Ltd. New Delhi. pp. 48. 
Paleg, L.G. (1960). Physiological effects of gibberellic acid II. Plant Physiology. 35: 902-906.

Panse, V.G. and Sukhatme, P.V. (1967). Statistical Methods for Agricultural Workers. ICAR, New Delhi.

Patel, R.J., Ahlawat, T.R., Patel, A.I., Amarcholi, J.J., Patel, B.B. and Sharma, K. (2017). Growth of mango (Mangifera indica L.) rootstocks as influenced by pre-sowing treatments. Journal of Applied and Natural Science. 9(1): 582-586.

Patel R.J., Ahlawat, T.R., Singh, A., Momin S.K. and Gavri, C. (2016). Effect of pre-sowing treatments on stone germination and shoot growth of mango (Mangifera indica L.) seedlings. International Journal of Agricultural Sciences. 8 (52): 2437-2440.

Patil, S.S. and Krishna, A. (2016). Influence of seed moisture content on seed germination and quality in canes. Journal of Plant Science Research. 3 (2): 1-4.

Rajamanickam, C., Anbu, S. and Balakrishnan, K. (2004). Influence of seed treatments on seedling vigour in amla (Emblica officinalis G.). South Indian Journal of Horticulture. 52(6): 324-327.
Ross, J.J., O’Neill, D.P., Wolbang, C.M., Symons, G.M. and Reid, J.B. (2002). Auxin-gibberlin interactions and their role in plant growth. Journal of Plant Growth Regulation. 20: 346-353.

Sihi, S., Bakshi, S. and Sengupta, D. N. (2015). Detection of DNA polymerase $\lambda$ activity during seed germination and enhancement after salinity stress and dehydration in the plumules of Indica rice (Oryza sativa L.). Indian Journal of Biochemistry and Biophysics. 52(1): 86-94.

Vachhani, K.B., Gohil, J.H., Pandey, R. and Ray, N.R. (2014). Influence of chemicals, $P G R^{1 / 4 s}$ and cow-dung slurry as seed treatment on germiability, growth and development of khirnee (Manilkara hexandra Roxb.) under net house condition. Trends in Bioscience. 7(14): 1641-1643.

Vasantha, P.T., Vijendrakumar, R.C., Guruprasad, T.R., Mahadevamma, M. and Santhosh, K.V. (2014). Studies on effect of growth regulators and biofertilizers on seed germination and seedling growth of tamarind (Tamarindus indica L.). Plant Archieves. 14(1): 155-160.

Vijaya, N. and Satyanarayana, G. (2004). Mango Research in Andhra Pradesh. Annual Report 2004-05, Fruit Research Station, Sangareddy. pp. 1-15. 